\title{
The Alien Citizen: Social Distance and the Economic Returns to Naturalization in the Southwest
}

\author{
By \\ Peter Catron \\ Department of Sociology \\ University of Washington \\ catron@uw.edu \\ Working Paper \\ (last updated 12/26/2020)
}

\begin{abstract}
Citizenship acquisition is often promoted as one factor that can facilitate the economic integration of immigrants. However, not all individuals and groups experience positive benefits to naturalization. This article argues that social distance from the native-born is an important factor that influences who does and does not benefit from citizenship acquisition. Specifically, I create a new continuous measure of social distance for immigrants during the age of mass migration. I show that the relationship between social distance and the economic returns to citizenship takes an inverted U-shape. Those considered closest and furthest away in social distance to the native-born report little to no advantages to citizenship while those in the middle report larger returns. I then focus on the Mexican population in the historical southwest and take advantage of a unique enumeration in the complete count 1930 US census that coded Mexicans as either white or Mexican. Mexicans coded as white report economic differences between citizenship statuses while Mexicans coded as nonwhite report no difference between citizenship statuses. The results suggest citizenship may not be beneficial to all individuals and groups depending on where they fall in the ethnoracial hierarchy.
\end{abstract}




\section{The Alien Citizen: Social Distance and the Economic Returns to Naturalization in the Southwest}

For over a century, immigrant occupational outcomes have been directly linked to their citizenship status in the United States. Laws and employer practices give occupational advantages to citizens over noncitizens through hiring and promotion (Bratsberg, Ragan, and Nasir 2002; Scott 2008; Peters, Vink, and Schmeets 2017; Hainmueller, Hangartner, and Ward 2019). This creates inequalities within and between immigrant groups where those who become US citizens secure better life chances than noncitizens. As a result, scholars often point to citizenship as a "master status," where completing the process of naturalization is considered the only protection against barriers to better occupational attainment because of one's citizenship status (Tienda 2002). However, empirical research has shown that the size of citizenship's effect on occupational outcomes is not universal for all immigrant groups (Catron 2019; Hainmueller, Hangartner, and Ward 2019; Asad and Clair 2018). There are considerable differences in occupational advantages afforded to citizens over noncitizens where full citizenship is not necessarily a mechanism that can override other social forces that prevent some immigrants from achieving better occupational attainment. In the first half of the twentieth century, the importance of status citizenship increased producing economic differences within and between European immigrant populations (Catron 2019; Schneider 2001). However, less is known about why there is variation in the benefits to citizenship acquisition among other immigrant groups eligible to naturalize.

This article seeks to understand the conditions that allowed for greater or lesser economic returns to citizenship acquisition in the first half of the twentieth century. Specifically, it analyzes the role social distance from the native-born plays in promoting greater or fewer benefits to citizenship. First, I develop a measure of social distance of immigrant groups from the native- 
born to assess its relationship to the returns to becoming a citizen. I use the 1930 complete-count census (Ruggles et al. 2015) and focus on Canadian, Mexican, and European immigrants living in the southwest. I find that the relationship between the economic returns to citizenship and social distance takes an inverted U-shape. Groups perceived to be the closest and furthest away in social distance to the native-born report little to no occupational differences between those who naturalized and those who did not. However, groups in-between the social distance extremes report large occupational advantages. I then analyze within-group differences by taking advantage of a unique enumeration of the 1930 census that classifies Mexicans into two racial groups: white and Mexican. ${ }^{1}$ I assess whether there was a relationship between the returns to citizenship and social distance within this particular group. Mexicans as a group did not experience returns to citizenship as their European and Canadian counterparts. However, this result is driven by Mexicans perceived to be nonwhite. Mexicans who were perceived to be white in the 1930 census held an occupational premium if they had become naturalized compared to those who had not completed the naturalization process. This suggests a strong relationship between social distance and citizenship when analyzing economic outcomes. I conclude by discussing the relationship of social distance and the economic returns to citizenship.

\section{Citizenship, Social Distance, and Occupational Outcomes in the Age of Mass Migration}

From its onset, citizenship policies in the United States were directly targeted towards including and later excluding certain European groups. Before 1906, citizenship policy was designed to lure European immigrants to come to the US and seize control of the territory from

\footnotetext{
${ }^{1}$ Following Fox and Bloemraad (2015), I use "Mexican" and "nonwhite" interchangeably when discussing the 1930 racial category throughout this article.
} 
indigenous groups and create a self-sustaining economy and independent state (Ueda 1992). European immigrants enjoyed liberal naturalization proceedings, which were designed to help induce more migration. As a result, citizenship played little role in creating economic inequalities between individuals since it was easy to obtain and laws rarely tied citizenship status to occupational status. However, as the costs to migration diminished due to changes in steamship technology and the lifting of poverty constraints in sending countries that led to a large influx of southern and eastern European immigrants beginning around 1880, the US no longer needed inducement policies and instead began shifting towards restriction where access to naturalization became harder.

The shift to restriction policies at the turn-of-the-twentieth century was part of the broader restriction movement that sought to limit certain immigrant groups' access to the territory and franchise. Due to the population influx, reactions against immigration became more potent. Politicians and the native-born were worried that easy naturalization increased immigrant political influence and Catholic immigrants and their sympathizers would take control of Congress (Parker 2015; Ueda 1992). The 1906 Naturalization Act codified the requirements of naturalization, which made it harder for immigrants to naturalize (Bloemraad 2006). The Naturalization Act established the Bureau of Immigration and Naturalization, created a standard application form, added the need to demonstrate command of English by answering basic civics questions and imposed a fee to pay for administrative costs. Becoming a citizen was a two-step process where immigrants first had to declare their intent to become a citizen before formally petitioning to become a citizen. The new law curtailed naturalization rates of some immigrant groups, especially for southern and eastern Europeans who found the English requirements difficult and administrative fees high (Bloemraad 2006). 
At the same time that it became harder to naturalize, states, localities, and private employers began amplifying differences between citizens and noncitizens. Laws and policies blocked noncitizens from some occupations, restricted noncitizen employment on public works projects, and developed "Americans First" policies that would only promote citizens (see Catron 2019). Noncitizens often worked in secondary sectors or in laborer positions within firms that had little chance for better attainment (Catron 2016). Only after becoming a citizen would firms allow for promotions into craft and managerial positions for immigrants. Similarly, state laws across the country blocked noncitizens from many white-collar jobs and many cities did not allow noncitizens to work on public works projects such as building roads and bridges. Although these laws and policies were not strictly enforced in all cases, the preference given to citizens over noncitizens generated inequalities within European groups that persisted across generations (Catron 2019).

The reactions against immigration that sparked stricter naturalization policies occurred mostly where European immigrants settled. Yet these laws and practices also spilled over to Mexicans who were also eligible to naturalize. Whereas Americanization efforts were designed to make southern and eastern European immigrants members of the country leading to better occupational attainment, however, Mexican immigrants in the southwest were socialized into accepting low-level jobs and obedience to employers (Laslett 2012; Fox 2015). For many Mexicans, engaging in strategies for better attainment, such as becoming a citizen, held little reward as they did for their European counterparts. In part, this is due to their position in relation to the white-nonwhite boundaries established at the time (Alba 2005; Fox and Guglielmo 2012). Although Europeans occupied a nonwhite status (Roediger 1994; but see also Fox and Guglielmo 2012), the native-born viewed Mexicans as permanently foreign and unassimilable 
(Alba 2005; Sanchez 1992; Ngai 2003). However, Mexicans were differentiated by their skintone as the native-born recognized that some Mexicans were of European descent while others were a mix of European and Indian ancestries (Gratton and Merchant 2016). The differentiation in color status among Mexicans would have large effects on the economic assimilation and effects of naturalization (Sanchez 1992).

At the height of the Age of Mass Migration, Mexican immigrants comprised a small share of the immigrant flow and stock. Mexicans initially entered the US territory following the Mexican-American War of 1846-48 when the newly formed border crossing Mexican citizens already living in the southwest. Soon after, Mexicans began entering the US seeking temporary and permanent residency. The racial and ethnic hierarchy that Mexicans entered was often tenuous as these immigrants straddled the boundary between white and nonwhite (Fox and Guglielmo 2012). By law, Mexicans were eligible for naturalization, a designation reserved for free white men at the time. The Treaty of Guadalupe Hidalgo (1848) ensured that Mexicans in the newly incorporated territories of the US following the Mexican-American War were allowed to become citizens (Menchacha 2011). After a series of failed court cases that challenged Mexican's color status and claims to the state, Mexicans became "white by law" (Fox and Bloemraad 2015). However, in practice, Mexicans were often judged to be nonwhite by the native-born that severely limited life chances.

Unlike the factory owners in the North and Midwest that encouraged naturalization and provided economic advantages to naturalized Europeans, growers in the southwest had little interest in these efforts since employers preferred an unassimilated workforce (Fox 2015). Employers reassured restrictionists that Mexican immigrants were temporary, only in the US for harvests, so targeting Americanization efforts at this group was less desirable. This led to a cheap 
and disposable workforce that farming industries could use for seasonal work. At times, restrictionists in the southwest would pass alienage laws similar to those found in the North and Midwest. However, they were often short-lived as they were considered too extreme and violated constitutional rights or they were unevenly enforced. For instance, in Arizona, a statute provided that eighty percent of all employees had to be citizens if a company employed over five people (Konvitz 1946). This law fell disproportionately on agricultural employers who generally hired a noncitizen Mexican workforce. This statute was eventually overturned in the US Supreme Court for violating the equal protection clause in the Fourteenth Amendment (Traux v. Raich 1915239 U.S. 33). Other laws, however, affected noncitizen Mexicans, but these laws were not always enforced. For instance, in Arizona and New Mexico, alien land laws prevented noncitizens from owning land. While Arizona violently enforced these laws, New Mexico did not (Jacobson, Tichenor, and Durden 2018).

At the same time, backlash against Mexican immigrants increased during this period due to a raid by Pancho Villa in New Mexico during the Mexican Revolution in 1916 and fears that Mexico would join Germany during WWI in an alliance against the US (Laslett 2012). The "brown scare" led to native-born beliefs that Mexicans were an inferior race and their loyalty to the US suspect (Laslett 2012). As a result, proponents of Americanization programs did not promote citizenship and better attainment for Mexicans like they did for Europeans, but rather encouraged acceptance into a lower social standing in the US. Yet, treatment by the native-born was variable throughout the US since Mexicans occupied complex positions in relation to whitenonwhite boundaries (Fox and Guglielmo 2012). As noted, Mexicans were considered "white by law," but this boundary was not institutionalized consistently at the federal, state, and local levels. On the one hand, the boundary between Mexicans and native-white populations was 
structured such that Mexican opportunity structures were limited given their membership to a group (Alba 2005). However, in particular contexts and circumstances, Mexican's individual characteristics, such as their skin tone, education, and class, would allow them to be accepted as native white populations (Fox and Guglielmo 2012).

There was ambiguity in Mexican's social status that led to processes of inclusion and exclusion within the group. As noted by Fox and Guglielmo (2012), differences between white populations and Mexicans were widely recognized, but only sometimes institutionalized depending on factors such as geography and time period. This meant that Mexicans would sometimes be included in the "mainstream," but could also be excluded from the "mainstream." Factors that affected who and when individuals would be included in various aspects of "mainstream" life were often dependent on skin tone, class, and educational attainment that would bring some individuals closer to the native-born than others (Sanchez 1992). As Fox and Bloemraad (2015) find, immigrants who held these characteristics in the 1930 census were more likely to become a citizen. Mexicans included in mainstream life had access to better opportunity structures that would promote better outcomes. This means that citizenship may have facilitated better occupational attainment for these individuals similar to European groups. The remainder of this article seeks to understand the relationship between social distance and economic returns to citizenship. I discuss how social distance is measured both between and within immigrant groups and then assess the economic returns to citizenship acquisition.

\section{Measuring Social Distance in the Age of Mass Migration}

To measure social distance in the age of mass migration, I follow methodology similar to Hilger (2016) and Kosak and Ward (2019) that creates a social distance scale based on the rank 
of various nationalities of 32 different samples from 14 studies published between 1925 and 1956. Introduced by Robert Park (1924) and further tested by his student Emory Bogardus and others, measures of racial differences were developed throughout the 1920s, 30s, and 40s. Researchers asked respondents, who were mostly white students at universities, to express preferences over various nationalities and races using two main methodologies. ${ }^{2}$ The first methodology consisted of "social distance" scaling based on how much intimacy with particular groups a respondent deemed acceptable (Bogardus 1926). These studies asked individuals to place racial groups on a scale of seven categories: "would marry into group," "would have as close friend," "would have as next-door neighbors," "would work in same office," "have as speaking acquaintances only," "have as visitors only to my nation," and would "debar from my nation." Researchers then developed a scale that ranked nationalities and races given how nativewhite respondents answered these questions. The second main methodology included pairwise group comparison scaling (Thurstone 1928). These studies asked individuals "which of the following two nationalities would you prefer to associate with" in many pairwise comparisons and then constructed a scale based on distributional assumptions about individual racial preferences. $^{3}$

Table 1 presents the rank of selected nationalities that appear most commonly in the historical studies who are eligible to naturalize. For purposes of comparison, I also include the rank of native-born blacks. By presenting the rank of each group from each study, I ignore the

\footnotetext{
2 These samples are unlikely to be representative of anything. However, that most of the respondents are college students is an advantage in the analyses since they are likely to become employers or managers who may act on these prejudices.

${ }^{3}$ A third methodology constructed by Young (1927) asked subjects to rank nationalities by "innate ability" to a course of undergraduate students at the University of Pennsylvania; the study shows that even after a semester-long course advancing opportunity-based theories of racial outcome differences, prejudice does not change.
} 
cardinal scales produced by these original studies. While the original scales likely contain valuable information about the strength of preferences (see, e.g., Boyd 2019), the rank allows for direct comparison across all studies to develop a median distance from the native-born. These rankings are based on a 0 to 1 scale, where 0 means no prejudice against the group and 1 means complete prejudice against the group. As shown, groups fall on a range of social distances with Canadians and English immigrants considered the closest in social distance and Mexican and African-Americans considered the furthest. Other groups that typically scored poorly on all scales included Chinese, Japanese, Turks, and Hindus. These groups, are not included in the table since they were either formally barred from naturalization or small in numbers and geographically concentrated in small areas.

\section{[TABLE 1 HERE]}

The two main methodologies used from the original studies produce slightly different scaling where pairwise comparisons assign a larger rank for Irish, Swedes, Poles, and US-born black populations compared to the social distance studies. Mexicans report a much lower ranking in the pairwise comparisons mostly due to the low ranking provided by children in the St. Louis samples in the Meltzer (1939) study. The samples taken from the southwest in the Bogardus studies reports stronger prejudice against Mexicans than at the national-level. This is somewhat unsurprising since anti-Mexican practices described above were primarily concentrated in the Southwest where Bogardus did his studies. In addition, this area is where the majority of Mexicans settled sparking greater exposure between groups. The salience of the Mexican population was larger in the southwest than in places with small numbers of Mexican workers.

The social distance rank allows for comparisons between groups depending on how mostly white college students perceived different groups. However, it does not describe along 
what dimension any prejudices emerge. To gain further leverage on the relationship between citizenship and social distance, therefore, I next use a unique enumeration of the full count 1930 census. The 1930 census is the only historical census that allowed enumerators to classify Mexican immigrants and their children into two racial categories: white and Mexican. Prior and after 1930, Mexicans were classified as white in every census. The concept of including a Mexican racial category emerged from the Census Bureau as many realized that Mexicans comprised people of European descent as well as mestizos who were a mix of European and Indian ancestries (Gratton and Merchant 2016). ${ }^{4}$ Although long established Mexican populations in places like northern New Mexico fought any nonwhite classification, recent arrivals were less politically mobile and were often split into white and nonwhite categories (Gratton and Merchant 2016). Enumerators in the 1930 Census were instructed to make independent judgements about the color of Mexicans. The Census instructed enumerators to classify individuals born in Mexico or with parents born in Mexico to code an individual's race as Mexican if they were "not definitely white" (United States 1933: 27). Individuals with Mexican heritage who were perceived to be Black, Indian, Chinese, or Japanese were instructed to be labeled as Mexican in the racial box. ${ }^{5}$ While there were no specific instructions on what constituted "definitely white," enumerators appear to have employed a narrow definition of whiteness (Fox and Bloemraad 2015).

${ }^{4}$ Hoschild and Powell (2018) argue that Congress placed pressure on the Census Bureau to distinguish whites from Mexicans instead of the Census Bureau creating the idea itself. Who came up with the idea, however, is unimportant for the analysis below.

${ }^{5}$ In some cases, enumerators did not follow these instructions and instead marked Indian, Black, etc. in the racial category for Mexicans. This was likely random as individuals marked with something other than Mexican or white were small in number. In the below analyses, I include individuals coded as something other than Mexican or white as Mexican following the Census's instructions. However, exclusion of these individuals in the below analyses do not change any substantive results. 
The goal of the 1930 racial categorization was to distinguish white and nonwhite individuals among the Mexican population. However, as found in Fox and Bloemraad (2015), Mexicans coded as white were more likely to speak English, have higher socioeconomic status, and own a home. This relationship is likely due to two reasons. The first reason is due to discrimination of darker Mexicans that allowed lighter Mexicans to hold higher socioeconomic characteristics. The second reason is due to enumerators being influenced by a person's social position to code that individual as white (i.e., if the person was a banker, the enumerator codes that person as white even if they have darker skin). Teasing out the reasons for being coded as white or non-white in the census remains outside the scope of these analyses. Importantly for these analyses, however, is that both mechanisms place "white" Mexicans in closer social distance to the native-born than "nonwhite" Mexicans. This therefore allows for analyses that split the Mexican population based off social distance to assess the economic returns to citizenship within group.

\section{Data and Methods}

To assess the economic returns of naturalization, I use the complete count 1930 US census (IPUMS; Ruggles et al. 2015). I limit the census to immigrant men who were born in either Europe, Canada, or Mexico and between the ages of 18 and 65. I also restrict the data to those who have lived in the US for more than five years due to the residency restrictions of citizenship. The focus on men is because citizenship labor market requirements were often targeted at occupations and industries dominated by men. In addition, over 80 percent of women were not in the formal labor market during this period and, as noted below, analyses require 
occupations to assess labor market outcomes for individuals. ${ }^{6}$ Given the theoretical interest in the Mexican population, I further limit the sample to immigrants living in the Southwest where 85 percent of the Mexican population lived. ${ }^{7}$ Since not all immigrant groups have a social distance rank as described above, I limit the sample to the ethnic groups described in Table 1.

Using the 1930 cross-section, I regress occupation income score on a set of control variables including the immigrant's citizenship status. The occupation income score (OCCSCORE) is calculated by IPUMS and reflects the median income of each occupation observed in the 1950 census in hundreds of dollars. The score is calculated by taking the median total income for each occupation published in a 1956 special report by the Census Bureau on occupational characteristics from a 3.33 percent sample of the population of both men and women. Occupations in the 1930 cross-section are assigned the corresponding 1950 value as a way to economically scale occupations on a continuous measure. The OCCSCORE is not a direct measure of income, but rather a measure of occupational attainment that is used in most research that analyzes economic outcomes of immigrants during this era.

The 1930 census asked all individuals born in another country their naturalization status including whether they had declared intent. Following Catron (2019), I compare citizens and noncitizens to those who have declared intent (first papers) to address concerns about selectivity. This group is a useful comparison for understanding the returns to citizenship since intending

\footnotetext{
${ }^{6}$ Seventeen percent of Mexican women in the 1930 census have a recorded occupation. Many of these recorded occupations revolve around housework or childcare. The primary advantages of citizenship for Mexican women during the time included the right to vote and some protection against deportation (see Menchacha 2011).

7 The Southwest is defined as Arizona, California, Colorado, Nevada, New Mexico, Texas, and Utah. Other receiving states with over 1 percent of the total Mexican population include Illinois (3.33 percent), Indiana (1.17 percent), Kansas (1.71 percent), and Michigan (1.51 percent). The remainder of the population lived throughout the United States.
} 
citizens likely hold characteristics and preferences similar to citizens given their interest in citizenship and ability to pay administrative fees, but they do not enjoy the benefits of full citizenship (see Catron 2019). The control variables also come from the 1930 census and include variables that are used in similar research: age and age squared, marital status, whether the individual can read and write, whether the individual can speak English, and years in the US and its square. I also control for a state fixed effect. I am therefore implicitly comparing immigrants who settled in the same places. To create a continuous measure of social distance for each ethnic group, I assign each group their median social distance rank from Table 1. First, I estimate the following model:

$$
\begin{aligned}
\operatorname{OCCSCORE}_{i}= & \alpha+\beta_{1} \text { NONCIT }_{i}+\beta_{2} \text { CIT }_{i}+\beta_{3} \text { SOCIALD }_{j}+\beta_{4} \text { SOCIALD SQRD }_{j} \\
& +\gamma X_{i}+e
\end{aligned}
$$

where $\operatorname{OCCSCORE}_{i}$ is the natural $\log$ of occupational income of person $i ; X_{i}$ is a vector of control variables noted above; $\operatorname{NONCIT}_{i}$ is a dummy variable $(1,0)$ if the individual is a noncitizen and $C I T_{i}$ is a dummy variable $(1,0)$ if the individual is a citizen. The reference category for NONCIT $_{i}$ and CIT $_{i}$ is the group of individuals who have declared intent to naturalize. SOCIALD refers to the median social distance of each ethnic group $j$ from Table 1 . Standard errors in the model are clustered by individual's birthplace.

Equation 1 presents the returns to citizenship in the Southwest in 1930. However, the theorized relationship between citizenship and social distance suggests an inverted-U shape where groups closest and furthest away in social distance having the lowest returns to citizenship, while groups in the middle having the largest returns to citizenship. To allow for the nonlinear effect of citizenship and social distance, I add interaction terms to equation 1 where: 


$$
\begin{aligned}
\text { OCCSCORE }_{i}= & \alpha+\beta_{1} \text { NONCIT }_{i}+\beta_{2} \text { CIT }_{i}+\beta_{3} \text { SOCIALD }_{j}+\beta_{4} \text { SOCIALD SQRD }_{j} \\
& +\beta_{5} \text { SOCIALD }_{j} * \text { NONCIT }_{i}+\beta_{6} \text { SOCIALD SQRD }_{j} * \text { NONCIT }_{i} \\
& +\beta_{7} \text { SOCIALD }_{j} * \text { CIT }_{i}+\beta_{8} \text { SOCIALD SQRD }_{j} * \text { CIT }_{i}+\gamma X_{i}+e
\end{aligned}
$$

I estimate the marginal effects from equation 2 to report the differences in occupational income between citizens and noncitizens compared to intending citizens across the range of the social distance rank. Similar to equation 1, the standard errors are clustered by birthplace in equation 2 .

The above analyses provide differences between immigrant groups. To assess whether there were differences in economic returns to citizenship within the Mexican population, I restrict the above data to only Mexican men. I create a dummy variable for whether the individual was coded as white by enumerators in the census. I fit the following model:

$$
\begin{gathered}
\operatorname{OCCSCORE}_{i}=\alpha+\beta_{1} \text { NONCIT }_{i}+\beta_{2} \text { CIT }_{i}+\beta_{3} \text { WHITE }_{i}+\beta_{4} \text { WHITE }_{j} * \text { CIT }_{i}+\gamma X_{i} \\
+e
\end{gathered}
$$

where again $\operatorname{OCCSCORE} E_{i}$ is the natural log of occupational income of person $i ; X_{i}$ is a vector of control variables noted above; $C I T_{i}$ is a dummy variable $(1,0)$ if the individual is a citizen as opposed to a noncitizen or intending citizen. Unlike the analyses above, I combine noncitizens with intending citizens due to low cell count of intending citizens. WHITE $E_{i}$ is a dummy category for whether the individual was coded as white. I also interact the white category with the citizenship category to interpret outcomes between citizenship and racial groups. The results from these analyses, therefore, include some selection effects when determining whether different groups experienced an economic premium to citizenship acquisition.

Table 2 presents the descriptive statistics of the 1930 sample. As shown, the majority of the immigrant population lives in either California or Texas. In part, this is due to the large concentration of Mexican men in these states. The majority of immigrants in the southwest also remained noncitizens, while 38 percent of the population had become citizens. Once the sample 
is limited to the Mexican population, however, those who were coded as white by enumerators were more likely to be citizens versus those who were coded as non-white. This corroborates Fox and Bloemraad's (2015) study on the determinants of citizenship using a smaller sample of the same data. Similarly, Mexicans were more likely to be coded as white if they were living in California versus living in Texas. White Mexicans, on average, also hold higher occupational income, are more likely to speak English, and hold more years in the US than nonwhite Mexicans. While white Mexicans were less likely to be married, they were also more likely to have the ability to read and write.

[Table 2 Here]

\section{Results}

The results begin by predicting occupational income of the pooled immigrant male population living in the southwest in 1930. As noted, I use intending citizens as the reference group to help control for selection into citizenship. A positive difference between naturalized citizens and intending citizens is interpreted as a citizenship advantage net of selective processes into citizenship. The models also include the immigrant groups' social distance rank from Table 1 where the larger the value, the further the distance from native-born whites.

Table 3 presents the results of equation 1 above predicting the natural $\log$ of occupational income using the pooled sample of all immigrant men living in the southwest. For ease of interpretation, the results of the non-logged occupational income converted into 2010 dollars are also reported in model 5. The first model reports the unadjusted means of citizenship statuses compared to those who have declared intent to naturalize. Immigrant men who were noncitizens in 1930 were concentrated in occupations that paid significantly less than intending citizens. 
Similarly, immigrants who have completed the naturalization process were concentrated in occupations that paid eight percent more than immigrants who have declared intent. These results corroborate prior studies that suggest better outcomes for citizens over intending citizens and aliens. As control variables are added to the model, citizenship continues to exert a positive influence on occupational income relative to intending citizens. Once all control variables are included, citizens are concentrated in occupations that pay over seven percent more than their intending citizen counterparts while noncitizens are concentrated in occupations that pay over five percent less than their intending citizen counterparts.

The immigrant group's social distance rank in Table 3 also shows a negative influence on occupational income: groups are concentrated in lower paid occupations as social distance increases. This is somewhat unsurprising since the historical social distance surveys were deeply influenced by differences in socioeconomic status (Boyd 2019). That is, social distance attitudes toward different European and Mexican ancestry were significantly influenced by their groups' overall occupational distribution (Boyd 2019). The larger the socioeconomic difference from the native-born (higher or lower), the more the native-born viewed these groups as different. Since most of the groups that hold larger social distances included in the sample held lower socioeconomic statuses (with the exception of Jewish immigrants), there is a clear negative relationship between occupational status and social distance. The significant effect of social distance rank, however, is not driven by group size. As noted in Table 2, roughly 42 percent of the sample is comprised of Mexican men. Given their large social distance rank and concentration in low-paid occupations, the effect of social distance may be driven by this group. However, model 4 of Table 3 runs the same regression, but omits Mexicans from the sample. 
There, social distance rank takes on an even greater negative effect suggesting that group size is not driving this result.

[Table 3 Here]

The above results suggest that citizenship has a positive influence on occupational outcomes while social distance has a negative influence on occupational outcomes in 1930. To assess the relationship between the two variables, Figure 1 plots the average marginal effects of citizenship status (predicted OCCSCORE $E_{\text {citizen }}-$ predicted OCCSCORE $E_{\text {intending citizen }}$, predicted $O C C S C O R E_{\text {noncitizen }}$ - predicted OCCSCORE $\left.E_{\text {intending citizen }}\right)$ across the range of social distance rank. As noted above, the social distance rank is a 0 to 1 score where 0 represents no social distance between an immigrant group and native-whites while 1 represents complete prejudice targeted towards a group. Figure 1 provides the direct test of the effects of citizenship and noncitizenship compared to intending citizens across the full range of social distance. Overlapping confidence intervals with the reference group means that there is no substantively significant difference between citizenship statuses at that particular social distance rank. Nonoverlapping confidence intervals with the reference group means that there is an effect (positive or negative) of citizenship status at that particular social distance rank.

The effect of citizenship across the range of social distance takes the hypothesized relationship. Those who are close in social distance and those who are furthest away in social distance show no returns to citizenship status compared to their intending citizen counterparts while those in the middle of the social distance rank show positive returns to citizenship. For instance, the effect of citizenship at a social distance rank of 0 , representing no social distance, is non-significant $\left(A M E_{c i t i z e n}=.009 ; p>.05\right)$. In addition, the effect of citizenship at social distance ranks greater than .7 , representing the furthest social distances, also show no significant 
effect. However, the effect of citizenship compared to intending citizens is significant for social distance ranks that fall in the middle suggesting positive economic returns for naturalization. For example, a social distance rank of .5 , representing the middle of the ranking, shows a significantly positive effect $\left(A M E_{\text {citizen }}=.105 ; p<.001\right)$.

While the occupational returns to citizenship takes an inverted U-shape, the effect of being an alien holds the opposite relationship. Groups with low and high social distance ranks shows no statistically discernable difference between aliens and intending citizens. However, those in the middle of the social distance rank report significantly lower occupational income compared to their intending citizen counterparts. For instance, a social distance rank of .5 shows significantly negative effects for noncitizens $\left(A M E_{\text {noncitizen }}=-.066 ; p<.001\right)$. Taken together, whether a group experiences a citizenship advantage is likely conditioned by their social distance from the native-born. Groups close in social distance are unlikely to need to rely on the signaling mechanisms described above, while greater social distance pushes immigrants into similar positions regardless of citizenship status. This indicates that groups who experienced the most prejudice were unlikely to experience any benefits of naturalization as other groups during this period in the Southwest.

[Figure 1 Here]

To gain further leverage on the relationship between social distance and the economic returns to citizenship, I next focus more specifically on the Mexican population. As noted, Mexicans straddled bright boundaries, which may have allowed some individuals within the group to experience a citizenship advantage and others not. That is, some Mexican immigrants occupied a social distance that was slightly closer to the native-born than others that was based off skin-tone and socioeconomic status. I therefore leverage the Mexican racial category in the 
1930 Census, which as noted above is highly correlated with these characteristics to assess whether some Mexicans experienced a citizenship advantage and others not. Due to low cell count of intending citizens among white Mexicans in the census, I combine noncitizens and those who have declared intent to naturalize and compare them to those who have naturalized.

As shown in Table 4, Mexicans who naturalized were concentrated in occupations that paid approximately 2-3 percent more than their intending citizen and noncitizen counterparts in models 1 and 2. This suggests a citizenship advantage among Mexicans who held the highest social distance in the analyses above. However, as control variables are added, the effect of citizenship betrays no substantively significant effect compared to other citizenship statuses. That is, net of other factors, there was little return to citizenship for Mexican immigrants in the past. These results are consistent with the results above that suggest little difference between citizenship statuses among groups furthest away in social distance from the native-born. Consistent with the alien citizen hypothesis, even if Mexicans became citizens, there was little economic reward to their citizenship status.

While there were little to no returns to citizenship among Mexicans in Table 4, Mexicans who were coded as white by enumerators were concentrated in occupations that paid between 13 and 14 percent more than Mexicans coded as nonwhite. As noted, the Mexican racial category distinguishes individuals by social distance, although the specific mechanism for this differentiation remains unknown (i.e. whether it is due to discrimination or due to other socioeconomic factors that whiten individuals). Nevertheless, these findings suggest that Mexican men in the southwest were not treated the same in the labor market, and this difference was based off social distance.

[Table 4 Here] 
The above results suggest that there were little returns to citizenship among the Mexican population in the southwest. However, to assess whether some individuals within the group experienced any benefits, I next interact citizenship status with the Mexican racial category. Figure 2 presents the marginal effects of citizenship for both white and nonwhite Mexicans in the 1930 census. As mentioned above, the noncitizen category in these analyses include both aliens and those who have declared their intent to naturalize. The citizen category includes only those who were naturalized.

As shown in Figure 2, Mexican immigrants who were categorized as nonwhite report no statistically substantive difference between citizens and noncitizens. Indeed, the effect of citizenship is slightly lower than the effect of being a noncitizen for this population. Consistent with the results above, groups who occupy greater social distance are unlikely to experience any benefits to citizenship. However, among Mexican immigrants coded as white in the 1930 census, there is a significant effect of citizenship. That is, white Mexicans who became citizens were concentrated in occupations that paid more than their noncitizen counterparts. As noted, Mexican immigrants who were coded as white likely occupied a closer social position to the native-born than Mexican immigrants who were coded as nonwhite. For the Mexican population, this suggests that the conditions that placed some individuals closer in social distance, whether due to discrimination or due to other factors that whitened them, brought other benefits such as higher returns to citizenship similar to Europeans during this period.

[Figure 2 Here] 


\section{Discussion/Conclusion}

Access to citizenship is often promoted as one factor that can facilitate the process of economic integration of immigrants (OECD 2011). However, the above analyses suggest that not all groups have the same occupational returns to citizenship acquisition. In part, differential returns to citizenship rely on groups' social distance to the native-born. On the one hand, groups who are close in social distance to the native-born do not need to signal to employers that they are positively selected or likely to remain in the US since employers already view them as good workers. As a result, members of these groups may not show any occupational advantages due to their citizenship status. On the other hand, groups who are further away do need to rely on signaling their citizenship to employers for better positions, which then stratifies groups depending on who naturalizes and who does not. Eventually, however, the economic returns to citizenship begin to diminish as social distance increases since discrimination takes a stronger form. As Mai Ngai (2002) notes, some groups are treated as "alien citizens" where immigrants obtain formal citizenship but remain alien in the eyes of the dominant group.

The above analyses indicate that the citizenship advantage in the historical southwest took the described inverted-U shape: those at the extremes of social distance stand to benefit little from citizenship acquisition while those in the middle stand to benefit most from citizenship acquisition. This corroborates prior studies that suggest a relationship between social distance and economic returns to citizenship (see, e.g., Hainmueller, Hangartner, and Ward 2019). However, unlike prior research, the current study directly measures social distance during the time using a number of studies performed between 1920 and 1950. These studies allow for a ranking of social distance that places Western European and Canadian immigrants on one end of the social distance scale and Eastern European and Mexican immigrants on the other end of the 
social distance scale. By providing the rank of each immigrant group, it is possible to uncover how social distance of groups relates to citizenship acquisition. Citizenship provided economic advantages for groups in the middle, who were largely Eastern Europeans, consistent with prior research (Catron 2019; Schneider 2001).

Mexican immigrants provide the best test for understanding the relationship between social distance and citizenship. Mexicans occupied the furthest social distance of any immigrant group in the above study, which makes it possible to test the relationship between the economic advantages of citizenship and high social distance rank. As a group, Mexicans did not show any statistical differences in occupational income between those who naturalized and those who did not. This is largely consistent with analyses that focus on between group differences and historical research. As Bogardus (1930) put bluntly, "the Mexican says even if he became a citizen Americans would still call him a dirty greaser" (74). Mexicans were unlikely to overcome racialization processes through obtaining formal citizenship as their European counterparts. In part, this is due to Mexicans unique circumstances during the period based off their racial categorization and low socioeconomic status (Alba 2005; Fox and Guglielmo 2012; Roediger 1994). Mexicans have been historically subjected to persistent discrimination and socioeconomic stagnation and have been racialized as nonwhite (Telles and Ortiz 2008; Ortiz and Telles 2012; Jiménez 2008). These conditions may ultimately override any individual qualifications such as citizenship acquisition that would allow for higher attainment. However, some Mexicans were treated as members in some circumstances that would allow them to benefit from factors such as citizenship.

Mexicans straddled boundaries that would have allowed some individuals to experience occupational returns to citizenship and others not. The conditions that brought Mexicans closer 
to the native-born included both physical attributes as well as socioeconomic characteristics. To assess the within-group differences, I leveraged a unique enumeration of Mexicans in the 1930 census that allowed enumerators to code Mexican immigrants as either white or nonwhite. As noted, this enumeration proxies mechanisms that place some Mexicans in closer social distance to the native-born than others. Those who were classified as white and became a citizen in the 1930 census report an occupational premium vis-à-vis those classified as white but did not naturalize. However, there are no statistically substantive occupational differences between citizens and noncitizens among those classified as nonwhite in the 1930 census. This suggests that individuals considered closer in social distance to the native-born within groups may benefit from citizenship even when the group as a whole does not yield positive returns.

The above study provides important insight into the processes of immigrant economic incorporation. Researchers generally point to causal processes of citizenship and its effects of integration in the labor market (Scott 2008; Peters, Vink, and Schmeets 2017; Hainmueller, Hangartner, and Ward 2019). However, empirical studies also report that some immigrant groups do not benefit from citizenship acquisition outside of selective processes into citizenship (Bratsberg, Ragan, and Nasir 2002). Processes of racialization may affect what groups and individuals benefit from the positive advantages status citizenship confers. Discrimination may overshadow immigrants' ability to find higher occupational advancement where stereotypical views towards phenotypically distinctive populations diminish the value of individual qualifications. Immigrants do not choose the racial and ethnic hierarchy for which they enter, but are nevertheless subjected to its forces that ultimately determine where in the stratification system they enter (Waldinger and Catron 2016). Membership in these groups may ultimately override chances of better occupational attainment than membership in other groups. In the age 
of mass migration, social distance from the native-born was associated with differences in economic benefits to citizenship. As scholars continue to debate the relative economic advantages of citizenship acquisition, individual and group social distance should be considered when determining who benefits and who does not from citizenship status changes.

\section{References}

Alba, Richard. 2005. "Bright vs. Blurred Boundaries: Second-Generation Assimilation and Exclusion in France, Germany, and the United States." Ethnic and Racial Studies 28(1): 20-49.

Asad, Asad and Matthew Clair. 2018. "Racialized Legal Status as a Social Determinant of Health." Social Science and Medicine 199: 19-28

Bloemraad, Irene. 2006. "Citizenship Lessons from the Past: The Contours of Immigrant Naturalization in the Early $20^{\text {th }}$ Century." Social Science Quarterly 87(5): 927-953.

Bogardus, Emory Stephen. 1925a. “Measuring Social Distances.” Journal of Applied Sociology 9: 299-308.

Bogardus, Emory Stephen. 1925b. “Social Distance and Its Origins.” Journal of applied Sociology 9: 216-226.

Bogardus, Emory Stephen. 1928. Immigration and Race Attitudes. Boston: D.C. Heath and Company.

Bogardus, Emory Stephen. 1930. “The Mexican Immigrant and Segregation.” American Journal of Sociology 36(1): 74-80.

Bogardus, Emory Stephen. 1947. “Changes in Racial Distance.” International Journal of Opinion and Attitude Research 1: 55-62. 
Bogardus, Emory Stephen. 1959. Social Distance. Los Angeles: Anitoch Press.

Boyd, Robert L. 2019. "Social Distance Reexamined: European Ancestry Groups in the Early Twentieth-Century United States.” Sociological Inquiry

Bratsberg, Brent, James F. Ragan Jr., and Zafar M Nasir. 2002. "The Effect of Naturalization on Wage Growth: A Panel Study of Young Male Immigrants.” Journal of Labor Economics 20(3): 568-597.

Brooks, Lee M. 1936. "Racial Distance and Education." Sociology and Social Research: An International Journal 21(2): 128-133.

Catron, Peter. 2016. "Made in America? Immigrant Occupational Mobility in the First Half of the Twentieth Century." American Journal of Sociology 122(2): 325-378.

Catron, Peter. 2019. "The Citizenship Advantage: Immigrant Socioeconomic Attainment across Generations in the Age of Mass Migration.” American Journal of Sociology 124(4): 9991042.

Catron, Peter. 2020. "The Melting-Pot Problem? Persistence and Convergence of Premigration Socioeconomic Status in the Age of Mass Migration.” Social Forces 99(1): 398-423.

Fox, Cybelle. 2012. Three Worlds of Relief: Race, Immigration, and the American Welfare State from the Progressive Era to the New Deal. Princeton University Press.

Fox, Cybelle, and Irene Bloemraad. 2015 “Beyond 'White by Law': Explaining the Gulf in Citizenship Acquisition between Mexican and European Immigrants, 1930.” Social Forces 94(1): 181-207.

Fox, Cybelle, and Thomas A. Guglielmo. 2012. "Defining America's Racial Boundaries: Blacks, Mexicans, and European Immigrants, 1890-1945.” American Journal of Sociology 118(2): 327-379. 
Gratton, Brian and Emily K. Merchant. 2016. "La Raza: Mexicans in the United States Census." Journal of Policy History 28(4): 537-567.

Guilford, J.P. 1931. "Racial Preferences of a Thousand American University Students." The Journal of Social Psychology 2(2): 179-204.

Hainmueller, Jens, Dominik Hangartner, and Dalston Ward. 2019. “The Effect of Citizenship on the Long-Term Earnings of Marginalized Immigrants: Quasi-Experimental Evidence from Switzerland.” Science Advances 5(12) essay 1610.

Hartley, Eugene. 1946. Problems in Prejudice. New York: Octogan Books.

Hilger, Nathaniel. 2016. "Upward Mobility and Discrimination: The Case of Asian Americans." No. w22748. National Bureau of Economic Research.

Hochschild, Jennifer L., and Brenna M. Powell. "Racial Reorganization and the United States Census 1850-1930: Mulattoes, Half-Breeds, Mixed Parentage, Hindoos, and the Mexican Race." Studies in American Political Development 22(1): 59-96

Jacobson, Robin Dale, Daniel Tichenor, and T. Elizabeth Durden. 2018. “The Southwest's Uneven Welcome: Immigrant Inclusion and Exclusion in Arizona and New Mexico.” Journal of American Ethnic History 37(3): 5-36.

Jiménez, Tomás R. 2008. "Mexican immigrant replenishment and the continuing significance of ethnicity and race." American journal of sociology 113(6): 1527-1567.

Katz, Daniel and Kenneth Braly. 1935. "Racial Prejudice and Racial Stereotypes." The Journal of Abnormal and Social Psychology 30(2): 175-193.

Konvitz, Milton R. 1946. The Alien and the Asiatic in American Law. Ithaca: Cornell University Press. 
Kosack, Edward and Zachary Ward. 2020. "El Sueño Americano? The Generational Progress of Mexican Americans Prior to World War II.” Working Paper.

Laslett, John H. 2012. Sunshine Was Never Enough: Los Angeles Workers, 1880-2010. University of California Press.

Meltzer, H. 1939. "Group Differences in Nationality and Race Preferences of Children.” Sociometry 2(1): 86-105.

Menchaca, Martha. 2011. Naturalizing Mexican Immigrants: A Texas History. University of Texas Press.

Ngai, Mae. 2003. Impossible Subjects: Illegal Aliens and the Making of Modern America. Princeton University Press.

OECD. 2011. Naturalization: A Passport for the Better Integration of Immigrants? Paris: OECD Ortiz, Vilma and Edward Telles. 2012. "Racial Identity and Racial Treatment of Mexican Americans." Race and Social Problems 4(1): 41-56.

Park, Robert E. 1924. "The Concept of Social Distance as Applied to the Study of Racial Attitudes and Racial Relations.” Journal of Applied Sociology 8: 339-344.

Parker, Kunal M. 2015. Making Foreigners: Immigration and Citizenship Law in America, 16002000. Cambridge University Press.

Peters, Floris, Maarten Vink, and Hans Schmeets. 2017. “Anticipating the Citizenship Premium: Before and After Effects of Immigrant Naturalisation on Employment." Journal of Ethnic and Migration Studies 44(7): 1051-1080.

Roediger, David R. 1994. Towards the Abolition of Whiteness: Essays on Race, Politics, and Working Class History. Verso. 
Saffir, Milton A. 1937. "A Comparative Study of Scales Constructed by Three Psychophysical Methods." Psychometrika 2(3): 179-198.

Schneider, Dorothee. 2001. "Naturalization and United States Citizenship in Two periods of Mass Migration: 1894-1930, 1965-2000.” Journal of American Ethnic History 21(1): 5082.

Scott, K. 2008. “The Economics of Citizenship: Is There a Naturalization Effect?” In The Economics of Citizenship, edited by P. Bevelander and D.J. DeVoretz, 105-127. Malmo: Malmo University Press

Telles, Edward and Vilma Ortiz. 2008. Generations of Exclusion: Mexican-Americans, Assimilation, and Race. Russell Sage Foundation.

Thurstone, L. 1928. “An Experimental Study of Nationality Preferences.” Journal of General Psychology 1: 405-425.

Tienda, Marta. 2002. "Demography and the Social Contract." Demography 39(4): 587-616 Ueda, Reed. 1992. "Naturalization and Citizenship." Pp. 734-748 in Harvard Encyclopedia of American Ethnic Groups edited by Stephan Thernstrom, Ann Orlov, and Oscar Handlin. Harvard University Press.

Waldinger, Roger, and Peter Catron. 2016. "Modes of Incorporation: A Conceptual and Empirical Critique." Journal of Ethnic and Migration Studies 42(1): 23-53.

Young, Donald. 1927. "The Effects of a Course on American Race Problems on the Race Prejudice of Undergraduates at the University of Pennsylvania." The Journal of Abnormal and Social Psychology 22(3): 235-242. 
Table 1: Rank-Score from Social Distance Studies from 1925-1959

\begin{tabular}{|c|c|c|c|c|c|c|c|c|c|c|c|c|c|c|}
\hline Study & English & Canadian & Irish & French & German & Swedish & Italian & Jewish & Russ. & Hung. & Polish & Greek & Mex. & Black \\
\hline Bogardus (1925a) & 0 & 0.05 & 0.13 & 0.15 & 0.33 & 0.26 & 0.41 & 0.74 & 0.56 & 0.51 & 0.54 & 0.67 & 0.79 & 0.82 \\
\hline Bogardus (1925b) & 0.03 & 0.03 & 0.33 & 0.22 & 0.81 & 0.31 & 0.5 & 0.85 & 0.33 & 0.69 & 0.47 & 0.75 & 0.81 & 1 \\
\hline Bogardus (1928) & 0 & 0.07 & 0.15 & 0.18 & 0.23 & 0.28 & 0.45 & 0.67 & 0.43 & 0.53 & 0.5 & 0.72 & 0.78 & 0.88 \\
\hline Bogardus (1947) & 0.08 & 0.06 & 0.11 & 0.17 & 0.31 & 0.25 & 0.53 & 0.64 & 0.39 & $\mathrm{n} / \mathrm{a}$ & 0.36 & 0.58 & 0.81 & 0.97 \\
\hline Bogardus (1959) & 0.1 & 0 & 0.17 & 0.13 & 0.27 & 0.2 & 0.4 & 0.53 & 0.8 & $\mathrm{n} / \mathrm{a}$ & 0.43 & 0.5 & 0.93 & 0.9 \\
\hline Brooks (1936) & 0 & $\mathrm{n} / \mathrm{a}$ & $\mathrm{n} / \mathrm{a}$ & 0.25 & 0.17 & $\mathrm{n} / \mathrm{a}$ & 0.42 & $\mathrm{n} / \mathrm{a}$ & $\mathrm{n} / \mathrm{a}$ & $\mathrm{n} / \mathrm{a}$ & $\mathrm{n} / \mathrm{a}$ & 0.5 & 0.58 & 0.83 \\
\hline Guilford (1931) & 0 & $\mathrm{n} / \mathrm{a}$ & $\mathrm{n} / \mathrm{a}$ & 0.2 & 0.13 & 0.27 & 0.4 & 0.6 & 0.47 & $\mathrm{n} / \mathrm{a}$ & $\mathrm{n} / \mathrm{a}$ & 0.53 & 0.67 & 0.8 \\
\hline Guilford (1931) & 0 & $\mathrm{n} / \mathrm{a}$ & $\mathrm{n} / \mathrm{a}$ & 0.13 & 0.2 & 0.27 & 0.47 & 0.53 & 0.4 & $\mathrm{n} / \mathrm{a}$ & $\mathrm{n} / \mathrm{a}$ & 0.6 & 0.67 & 0.87 \\
\hline Guilford (1931) & 0 & $\mathrm{n} / \mathrm{a}$ & $\mathrm{n} / \mathrm{a}$ & 0.27 & 0.13 & 0.2 & 0.47 & 0.53 & 0.4 & $\mathrm{n} / \mathrm{a}$ & $\mathrm{n} / \mathrm{a}$ & 0.67 & 0.8 & 0.73 \\
\hline Guilford (1931) & 0 & $\mathrm{n} / \mathrm{a}$ & $\mathrm{n} / \mathrm{a}$ & 0.2 & 0.13 & 0.27 & 0.4 & 0.53 & 0.47 & $\mathrm{n} / \mathrm{a}$ & $\mathrm{n} / \mathrm{a}$ & 0.6 & 0.8 & 0.87 \\
\hline Guilford (1931) & 0 & $\mathrm{n} / \mathrm{a}$ & $\mathrm{n} / \mathrm{a}$ & 0.13 & 0.2 & 0.27 & 0.47 & 0.53 & 0.4 & $\mathrm{n} / \mathrm{a}$ & $\mathrm{n} / \mathrm{a}$ & 0.6 & 0.67 & 0.73 \\
\hline Guilford (1931) & 0 & $\mathrm{n} / \mathrm{a}$ & $\mathrm{n} / \mathrm{a}$ & 0.2 & 0.13 & 0.27 & 0.4 & 0.53 & 0.47 & $\mathrm{n} / \mathrm{a}$ & $\mathrm{n} / \mathrm{a}$ & 0.6 & 0.73 & 0.87 \\
\hline Hartley (1946) & 0 & 0 & 0.12 & 0.24 & 0.21 & 0.15 & 0.5 & 0.77 & 0.56 & 0.47 & 0.62 & 0.74 & 0.88 & 0.72 \\
\hline Hartley (1946) & 0 & 0 & 0 & 0 & 0.27 & 0.24 & 0.33 & 0.47 & 0.62 & 0.7 & 0.44 & 0.53 & 0.85 & 0.7 \\
\hline Hartley (1946) & 0 & 0 & 0 & 0.26 & 0.29 & 0.24 & 0.41 & 0.52 & 0.56 & 0.71 & 0.35 & 0.65 & 0.65 & 0.35 \\
\hline Hartley (1946) & 0 & 0 & 0.38 & 0 & 0.32 & 0.38 & 0.59 & 0 & 0.2 & 0.5 & 0.5 & 0.74 & 0.79 & 0.82 \\
\hline Hartley (1946) & 0 & 0 & 0.15 & 0.12 & 0.26 & 0.29 & 0.44 & 0.47 & 0.59 & 0.65 & 0.74 & 0.56 & 0.88 & 0.62 \\
\hline Hartley (1946) & 0 & 0 & 0.24 & 0 & 0 & 0.24 & 0.38 & 0.44 & 0.32 & 0.5 & 0.56 & 0.68 & 0.85 & 0.85 \\
\hline Hartley (1946) & 0.12 & 0.21 & 0.15 & 0.24 & 0.15 & 0.24 & 0.38 & 0 & 0.59 & 0.59 & 0.41 & 0.59 & 0.78 & 0.82 \\
\hline $\begin{array}{l}\text { Katz and Allport } \\
\text { (1931) }\end{array}$ & 0.1 & 0.1 & $\mathrm{n} / \mathrm{a}$ & $\mathrm{n} / \mathrm{a}$ & 0.1 & $\mathrm{n} / \mathrm{a}$ & 0.5 & 0.4 & $\mathrm{n} / \mathrm{a}$ & $\mathrm{n} / \mathrm{a}$ & $\mathrm{n} / \mathrm{a}$ & 0.7 & $\mathrm{n} / \mathrm{a}$ & 1 \\
\hline $\begin{array}{l}\text { Katz and Braly } \\
\text { (1933) }\end{array}$ & 0.2 & $\mathrm{n} / \mathrm{a}$ & 0.4 & $\mathrm{n} / \mathrm{a}$ & 0.3 & $\mathrm{n} / \mathrm{a}$ & 0.5 & 0.7 & $\mathrm{n} / \mathrm{a}$ & $\mathrm{n} / \mathrm{a}$ & $\mathrm{n} / \mathrm{a}$ & $\mathrm{n} / \mathrm{a}$ & $\mathrm{n} / \mathrm{a}$ & $\mathrm{n} / \mathrm{a}$ \\
\hline
\end{tabular}


Table 1 (continued)

\begin{tabular}{|c|c|c|c|c|c|c|c|c|c|c|c|c|c|c|}
\hline Study & English & Canadian & Irish & French & German & Swedish & Italian & Jewish & Russ. & Hung. & Polish & Greek & Mex. & Black \\
\hline Meltzer (1939) & 0 & $\mathrm{n} / \mathrm{a}$ & 0.14 & 0.19 & 0.24 & 0.57 & 0.29 & 0.76 & 0.52 & $\mathrm{n} / \mathrm{a}$ & 0.62 & 0.71 & 0.45 & 1 \\
\hline Meltzer (1939) & 0 & $\mathrm{n} / \mathrm{a}$ & 0.19 & 0.14 & 0.24 & 0.38 & 0.86 & 0.71 & 0.52 & $\mathrm{n} / \mathrm{a}$ & 0.81 & 0.62 & 0.48 & 0.95 \\
\hline Meltzer (1939) & 0 & $\mathrm{n} / \mathrm{a}$ & 0.19 & 0.14 & 0.62 & 0.38 & 0.52 & 0.24 & 0.57 & $\mathrm{n} / \mathrm{a}$ & 0.71 & 0.76 & 0.48 & 0.95 \\
\hline Meltzer (1939) & 0 & $\mathrm{n} / \mathrm{a}$ & 0.29 & 0.19 & 0.14 & 0.52 & 0.33 & 0.62 & 0.9 & $\mathrm{n} / \mathrm{a}$ & 0.71 & 0.81 & 0.48 & 0.57 \\
\hline Meltzer (1939) & 0 & $\mathrm{n} / \mathrm{a}$ & 0.29 & 0.24 & 0.19 & 0.57 & 0.43 & 0.67 & 0.86 & $\mathrm{n} / \mathrm{a}$ & 0.53 & 0.62 & 0.71 & 0.86 \\
\hline Meltzer (1939) & 0 & $\mathrm{n} / \mathrm{a}$ & 0.24 & 0.14 & 0.19 & 0.48 & 0.57 & 0.76 & 0.62 & $\mathrm{n} / \mathrm{a}$ & 0.86 & 0.76 & 0.52 & 0.9 \\
\hline Meltzer (1939) & 0 & $\mathrm{n} / \mathrm{a}$ & 0.24 & 0.24 & 0.62 & 0.29 & 0.43 & 0.57 & 0.67 & $\mathrm{n} / \mathrm{a}$ & 0.71 & 0.48 & 0.33 & 0.9 \\
\hline Saffir (1937) & 0 & 0.12 & 0.28 & 0.28 & 0.2 & 0.36 & 0.6 & 0.72 & 0.64 & $\mathrm{n} / \mathrm{a}$ & 0.68 & 0.76 & 0.8 & 0.96 \\
\hline Thurstone (1928) & 0.1 & $\mathrm{n} / \mathrm{a}$ & 0.19 & 0.24 & 0.29 & 0.33 & 0.43 & 0.52 & 0.57 & $\mathrm{n} / \mathrm{a}$ & 0.62 & 0.67 & 0.81 & 1 \\
\hline Young (1927) & 0.13 & $\mathrm{n} / \mathrm{a}$ & 0.3 & 0.25 & 0.17 & 0.46 & 0.43 & 0.23 & 0.6 & $\mathrm{n} / \mathrm{a}$ & $\mathrm{n} / \mathrm{a}$ & 0.7 & 1 & 0.96 \\
\hline Young (1927) & 0.2 & $\mathrm{n} / \mathrm{a}$ & 0.4 & 0.38 & 0.1 & 0.46 & 0.47 & 0.23 & 0.63 & $\mathrm{n} / \mathrm{a}$ & $\mathrm{n} / \mathrm{a}$ & 0.71 & 0.96 & 1 \\
\hline Median & 0 & 0.015 & 0.19 & 0.195 & 0.205 & 0.28 & 0.435 & 0.53 & 0.56 & 0.56 & 0.56 & 0.67 & 0.785 & 0.87 \\
\hline $\begin{array}{l}\text { Median Social } \\
\text { Distance }\end{array}$ & 0 & 0 & 0.15 & 0.17 & 0.265 & 0.245 & 0.43 & 0.52 & 0.56 & 0.56 & 0.485 & 0.66 & 0.81 & 0.825 \\
\hline $\begin{array}{l}\text { Median Pairwise } \\
\text { Comparison }\end{array}$ & 0 & 0.12 & 0.24 & 0.2 & 0.2 & 0.33 & 0.45 & 0.585 & 0.52 & $\mathrm{n} / \mathrm{a}$ & 0.71 & 0.62 & 0.67 & 0.87 \\
\hline
\end{tabular}


Table 1 (continued)

\begin{tabular}{|c|c|c|c|c|c|}
\hline Study & $\begin{array}{c}\text { Number } \\
\text { of } \\
\text { Groups }\end{array}$ & Year & $\mathrm{N}$ & Sample & Method \\
\hline \multirow[t]{2}{*}{ Bogardus (1925a) } & & & & "Young business men or public & \\
\hline & 39 & 1925 & 110 & school teachers" & Social Distance \\
\hline Bogardus (1925b) & 36 & 1925 & 248 & US college/adult students & Social Distance \\
\hline Bogardus (1928) & 40 & 1926 & 1725 & US college/adult students & Social Distance \\
\hline Bogardus (1947) & 36 & 1946 & 1950 & US college/adult students & Social Distance \\
\hline Bogardus (1959) & 30 & 1956 & 2053 & US college/adult students & Social Distance \\
\hline Brooks (1936) & 12 & 1935 & 238 & U. North Carolina & Social Distance \\
\hline Guilford (1931) & 15 & 1931 & 198 & U. Florida & Pairwise Comparison \\
\hline Guilford (1931) & 15 & 1931 & 211 & U. Kansas & Pairwise Comparison \\
\hline Guilford (1931) & 15 & 1931 & 110 & U. Nebraska & Pairwise Comparison \\
\hline Guilford (1931) & 15 & 1931 & 208 & Northwestern U. & Pairwise Comparison \\
\hline Guilford (1931) & 15 & 1931 & 207 & U. Washington & Pairwise Comparison \\
\hline Guilford (1931) & 15 & 1931 & 62 & Wells College & Pairwise Comparison \\
\hline Hartley (1946) & 34 & 1938-39 & 132 & Princeton U. & Social Distance \\
\hline Hartley (1946) & 34 & 1938-39 & 86 & Teachers College & Social Distance \\
\hline Hartley (1946) & 34 & 1938-39 & 96 & Normal School & Social Distance \\
\hline Hartley (1946) & 34 & 1938-39 & 130 & C.C.N.Y. Business & Social Distance \\
\hline Hartley (1946) & 34 & 1938-39 & 144 & Columbia U. & Social Distance \\
\hline Hartley (1946) & 34 & 1938-39 & 39 & Bennington College & Social Distance \\
\hline Hartley (1946) & 34 & 1938-39 & 35 & C.C.N.Y. Arts & Social Distance \\
\hline Katz and Allport & 30 & 1931 & 3515 & Syracuse U. & Social Distance \\
\hline $\begin{array}{l}\text { Katz and Braly } \\
\text { (1933) }\end{array}$ & \multicolumn{2}{|c|}{ Katz and Braly } & 100 & Princeton U. & Pairwise Comparison \\
\hline \multirow[t]{2}{*}{ Meltzer (1939) } & & & & Children in a "very poor" & \\
\hline & 21 & 1934 & 320 & $\begin{array}{l}\text { neighborhood in St. Louis } \\
\text { Children in a "middle-class" }\end{array}$ & Pairwise Comparison \\
\hline Meltzer (1939) & 21 & 1934 & 769 & $\begin{array}{l}\text { neighborhood in St. Louis } \\
\text { Children in a "well-to-do" }\end{array}$ & Pairwise Comparison \\
\hline Meltzer (1939) & 21 & 1934 & 176 & neighborhood in St. Louis & Pairwise Comparison \\
\hline Meltzer (1939) & 21 & 1934 & 246 & Children in rural St. Louis County & Pairwise Comparison \\
\hline \multirow[t]{2}{*}{ Meltzer (1939) } & & & & Children in a private Catholic & \\
\hline & 21 & 1934 & 91 & school in St. Louis & Pairwise Comparison \\
\hline \multirow[t]{2}{*}{ Meltzer (1939) } & & & & Children in a private protestant & \\
\hline & 21 & 1934 & 268 & school in St. Louis & Pairwise Comparison \\
\hline \multirow[t]{2}{*}{ Meltzer (1939) } & & & & Children in a private non- & \\
\hline & 21 & 1934 & 44 & denominational school in St. Louis & Pairwise Comparison \\
\hline Saffir (1937) & 25 & $?$ & $?$ & U. Chicago & Pairwise Comparison \\
\hline Thurstone (1928) & 21 & 1928 & 239 & U. Chicago & Pairwise Comparison \\
\hline Young (1927) & 24 & 1927 & 221 & U. Pennsylvania & Innate Ability \\
\hline Young (1927) & 24 & 1927 & 231 & U. Pennsylvania & Innate Ability \\
\hline
\end{tabular}

Note: This table follows methods similar to Hilger (2016) and Kosack and Ward (2019), presenting the rankings of social distance of various nationality groups. Scale goes from 0 (minimum prejudice) to 1 (maximum prejudice). The NYU sample from the Guilford (1931) study is omitted since the sample was disproportionately Jewish-American and the Jewish children sample in the Meltzer (1939) study were omitted for similar considerations. The Howard University sample from Hartley (1946) is also omitted because the sample is disproportionately Black. 
Table 2: Descriptive statistics of immigrant men (18-65) living in the southwest, 1930 Census

\begin{tabular}{|c|c|c|c|c|c|c|}
\hline & \multicolumn{2}{|c|}{ Pooled Sample } & \multicolumn{2}{|c|}{ White Mexicans } & \multicolumn{2}{|c|}{ Nonwhite Mexicans } \\
\hline & $\begin{array}{c}\text { Mean/ } \\
\text { Proportion }\end{array}$ & $\begin{array}{l}\text { Standard } \\
\text { deviation }\end{array}$ & $\begin{array}{c}\text { Mean/ } \\
\text { Proportion }\end{array}$ & $\begin{array}{l}\text { Standard } \\
\text { deviation }\end{array}$ & $\begin{array}{c}\text { Mean/ } \\
\text { Proportion }\end{array}$ & $\begin{array}{l}\text { Standard } \\
\text { deviation }\end{array}$ \\
\hline Logged occscore & 3.07 & .405 & 3.102 & .396 & 2.947 & .338 \\
\hline \multicolumn{7}{|l|}{ Citizenship status } \\
\hline Alien & 52.60 & - & 64.09 & - & 91.74 & - \\
\hline First papers & 9.38 & - & 6.25 & - & 2.14 & - \\
\hline Citizen & 38.02 & - & 29.66 & - & 6.12 & - \\
\hline Social distance rank & .506 & .289 & & & & \\
\hline Age & 40.928 & 11.978 & 34.620 & 10.944 & 36.199 & 11.500 \\
\hline Literate & 85.81 & - & 89.96 & - & 72.20 & - \\
\hline Speaks English & 79.16 & - & 86.62 & - & 52.91 & - \\
\hline Years in US & 21.803 & 11.472 & 18.755 & 9.957 & 16.911 & 8.490 \\
\hline \multicolumn{7}{|l|}{ State } \\
\hline Texas & 24.33 & - & 22.89 & - & 47.15 & - \\
\hline California & 59.70 & - & 59.01 & - & 37.60 & - \\
\hline Arizona & 4.41 & - & 7.60 & - & 8.53 & - \\
\hline New Mexico & 1.75 & - & 3.37 & - & 3.07 & - \\
\hline Colorado & 6.27 & - & 2.75 & - & 2.60 & - \\
\hline Nevada & 1.13 & - & .88 & - & .53 & - \\
\hline Utah & 2.43 & - & 3.50 & - & .52 & - \\
\hline \multicolumn{7}{|l|}{ Ethnicity } \\
\hline English & 8.57 & - & & & & \\
\hline Canadian & 5.36 & - & & & & \\
\hline Irish & 2.21 & - & & & & \\
\hline French & 1.90 & - & & & & \\
\hline German & 7.78 & - & & & & \\
\hline Swedish & 4.85 & - & & & & \\
\hline Italian & 14.88 & - & & & & \\
\hline Jewish & 3.36 & - & & & & \\
\hline Russian & 3.63 & - & & & & \\
\hline Hungarian & .79 & - & & & & \\
\hline Polish & 1.13 & - & & & & \\
\hline Greek & 3.09 & - & & & & \\
\hline Mexican & 42.43 & - & & & & \\
\hline Sample Size & \multicolumn{2}{|c|}{427,258} & \multicolumn{2}{|c|}{3,857} & \multicolumn{2}{|c|}{177,441} \\
\hline
\end{tabular}

Note Data restricted to immigrant men who have lived in the US for at least five years and living in the southwest 
Table 3: Ordinary least squares estimates predicting logged and not-logged occupational income, 1930

\begin{tabular}{|c|c|c|c|c|c|}
\hline \multirow{4}{*}{$\begin{array}{l}\text { Citizenship status (first papers } \\
\text { reference) }\end{array}$} & \multicolumn{4}{|c|}{ LN(Occscore) } & \multirow{3}{*}{$\begin{array}{c}\text { Occscore }(\$ 2010) \\
\text { With Mexicans } \\
\text { Model }(5) \\
\end{array}$} \\
\hline & \multicolumn{3}{|c|}{ With Mexicans } & \multirow{2}{*}{$\begin{array}{c}\text { Without } \\
\text { Mexicans } \\
\text { Model (4) }\end{array}$} & \\
\hline & Model (1) & Model (2) & Model (3) & & \\
\hline & & & & & \\
\hline Alien & $\begin{array}{r}-.138 * * * \\
(.028)\end{array}$ & $\begin{array}{r}-.072 * * \\
(.019)\end{array}$ & $\begin{array}{r}-.054 * \\
(.018)\end{array}$ & $\begin{array}{r}-.061 * * * \\
(.007)\end{array}$ & $\begin{array}{r}-1404.824 * * \\
(386.973)\end{array}$ \\
\hline Citizen & $\begin{array}{r}.077 * * \\
(.018)\end{array}$ & $\begin{array}{r}.066 * * \\
(.019)\end{array}$ & $\begin{array}{r}.074 * * \\
(.017)\end{array}$ & $\begin{array}{r}.089 * * * \\
(.014)\end{array}$ & $\begin{array}{r}1694.853 * * \\
(385.673)\end{array}$ \\
\hline Social distance rank & & $\begin{array}{r}-.379+ \\
(.194)\end{array}$ & $\begin{array}{r}-.441 * \\
(.187)\end{array}$ & $\begin{array}{r}-.718^{*} \\
(.234)\end{array}$ & $\begin{array}{r}-8849.474+ \\
(4521.110)\end{array}$ \\
\hline Social distance rank-squared & & $\begin{array}{r}.169 \\
(.218)\end{array}$ & $\begin{array}{r}.292 \\
(.208)\end{array}$ & $\begin{array}{l}.871+ \\
(.464)\end{array}$ & $\begin{array}{r}5602.737 \\
(5176.776)\end{array}$ \\
\hline Age & & & $\begin{array}{r}.012 * * * \\
(.002)\end{array}$ & $\begin{array}{l}.009 * \\
(.004)\end{array}$ & $\begin{array}{r}275.699 * * \\
(60.672)\end{array}$ \\
\hline Age-squared & & & $\begin{array}{r}-.000 * * * \\
(.000)\end{array}$ & $\begin{array}{r}-.000 * * \\
(.000)\end{array}$ & $\begin{array}{r}-3.431 * * \\
(.772)\end{array}$ \\
\hline Literate $(=1)$ & & & $\begin{array}{r}.084 * * * \\
(.006)\end{array}$ & $\begin{array}{l}.085 * \\
(.029)\end{array}$ & $\begin{array}{r}1835.737 * * * \\
(163.152)\end{array}$ \\
\hline Speaks English $(=1)$ & & & $\begin{array}{r}.049 * * * \\
(.010)\end{array}$ & $\begin{array}{r}.075^{* *} \\
(.017)\end{array}$ & $\begin{array}{r}1187.578 * * \\
(303.100)\end{array}$ \\
\hline Years in US & & & $\begin{array}{r}.001 \\
(.001)\end{array}$ & $\begin{array}{r}-.001 \\
(.002)\end{array}$ & $\begin{array}{r}32.025 \\
(23.625)\end{array}$ \\
\hline Years in US-squared & & & $\begin{array}{r}-.000 \\
(.000)\end{array}$ & $\begin{array}{r}.000 \\
(.000)\end{array}$ & $\begin{array}{r}-.454 \\
(.480)\end{array}$ \\
\hline \multicolumn{6}{|l|}{ State (Texas ref.) } \\
\hline California & & & $\begin{array}{r}.017 \\
(.020)\end{array}$ & $\begin{array}{r}.001 \\
(.065)\end{array}$ & $\begin{array}{r}142.726 \\
(433.723)\end{array}$ \\
\hline Arizona & & & $\begin{array}{r}.038 * * \\
(.012)\end{array}$ & $\begin{array}{r}.035 \\
(.069)\end{array}$ & $\begin{array}{l}675.863 * \\
(285.338)\end{array}$ \\
\hline New Mexico & & & $\begin{array}{r}.012 \\
(.014)\end{array}$ & $\begin{array}{r}.024 \\
(.067)\end{array}$ & $\begin{array}{r}-32.827 \\
(326.336)\end{array}$ \\
\hline Colorado & & & $\begin{array}{r}-.046 \\
(.032)\end{array}$ & $\begin{array}{l}-.076 \\
(.075)\end{array}$ & $\begin{array}{r}-1301.141+ \\
(701.274)\end{array}$ \\
\hline Nevada & & & $\begin{array}{r}-.019 \\
(.031)\end{array}$ & $\begin{array}{r}-.060 \\
(.061)\end{array}$ & $\begin{array}{r}-772.004 \\
(554.971)\end{array}$ \\
\hline Utah & & & $\begin{array}{r}.004 \\
(.030) \\
\end{array}$ & $\begin{array}{r}-.031 \\
(.066) \\
\end{array}$ & $\begin{array}{r}-440.905 \\
(649.162) \\
\end{array}$ \\
\hline $\mathrm{N}$ & 427,258 & 427,258 & 427,258 & 245,960 & 427,258 \\
\hline R-squared & .064 & .083 & .098 & .056 & .118 \\
\hline
\end{tabular}

$+.05<\mathrm{p}<.1, * \mathrm{p}<.05, * * \mathrm{p}<.01, * * * \mathrm{p}<.001$ (two-tailed)

Note: Data limited to immigrant men $(18+)$ in the southwest who have lived in the US for more than five years.

Standard errors clustered by birthplace. 
Table 4: Ordinary least squares estimates predicted logged occupational income of Mexicans in the southwest, 1930

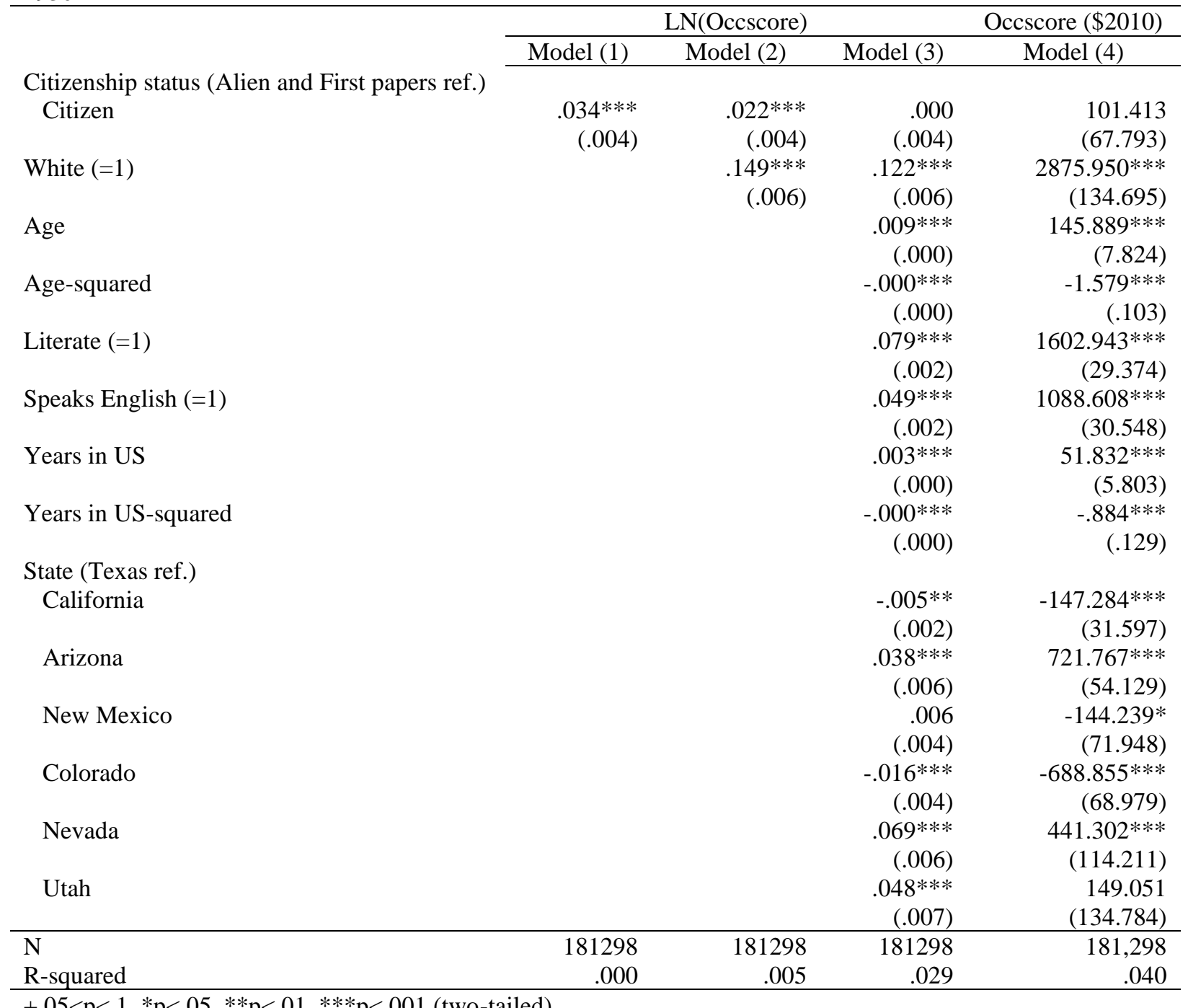

$+.05<\mathrm{p}<.1, * \mathrm{p}<.05, * * \mathrm{p}<.01, * * * \mathrm{p}<.001$ (two-tailed)

Note: Data limited to immigrant men $(18+)$ in the southwest who have lived in the US for more than five years. 


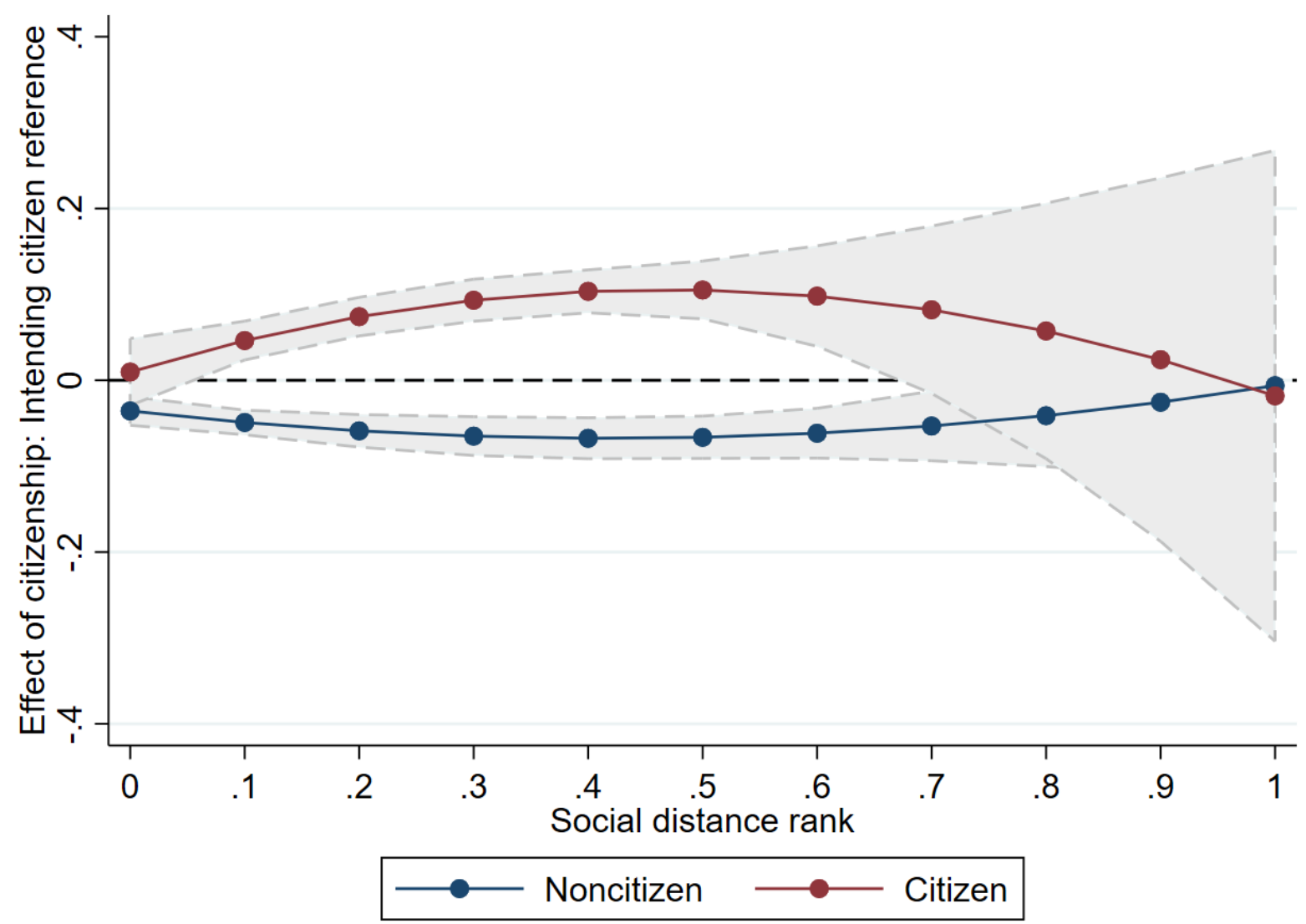

Figure 1: Average marginal effect of citizenship and noncitizenship (compared to intending citizens) across the range of social distance rank in the southwest 


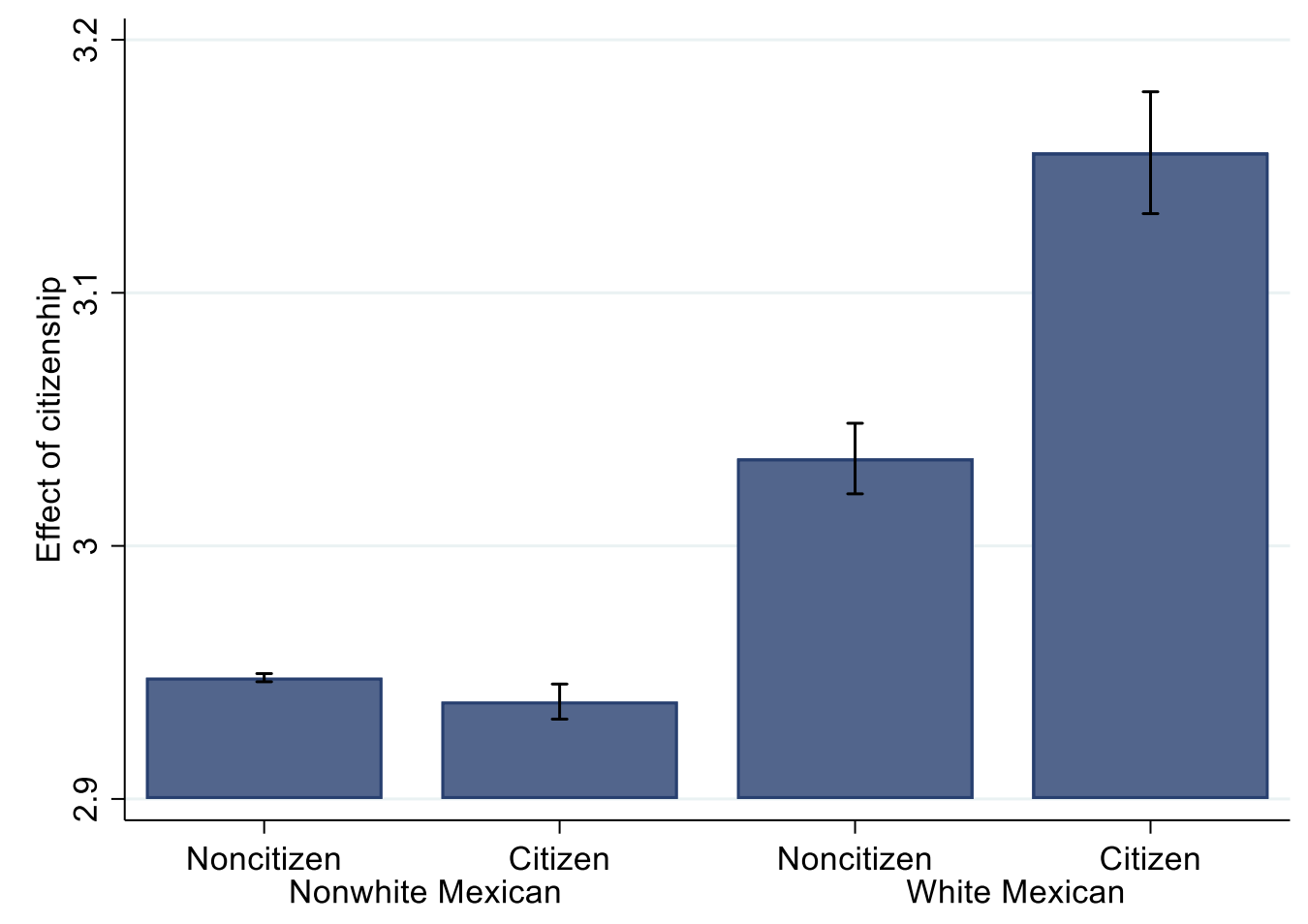

Figure 2: Average marginal effect of citizenship and noncitizenship for Mexican immigrant men living in the southwest 